\title{
Journey of Limonene as an Antimicrobial Agent
}

\author{
Akshi Gupta (iD), Ebenezer Jeyakumar $\mathbb{D}$ and Rubina Lawrence $\mathbb{D}$ \\ Department of Industrial Microbiology, Jacob Institute of Biotechnology and Bioengineering, Sam \\ Higginbottom University of Agriculture, Technology and Sciences, Prayagraj - 211 007, Uttar Pradesh, India.
}

\begin{abstract}
Injudicious consumption of antibiotics in the past few decades has arisen the problem of resistance in pathogenic organisms against most antibiotics and antimicrobial agents. Scenarios of treatment failure are becoming more common in hospitals. This situation demands the frequent need for new antimicrobial compounds which may have other mechanisms of action from those which are in current use. Limonene can be utilized as one of the solutions to the problem of antimicrobial resistance. Limonene is a naturally occurring monoterpene with a lemon-like odor, which mainly present in the peels of citrus plants like lemon, orange, grapefruit, etc. The study aimed to enlighten the antimicrobial properties of limonene as per previous literature. Advantageous contributions have been made by various research groups in the study of the antimicrobial properties of limonene. Previous studies have shown that limonene not only inhibits disease-causing pathogenic microbes, however, it also protects various food products from potential contaminants. This review article contains information about the effectiveness of limonene as an antimicrobial agent. Apart from antimicrobial property, some other uses of limonene are also discussed such as its role as fragrance and flavor additive, as in the formation of nonalcoholic beverages, as solvent and cleaner in the petroleum industry, and as a pesticide. Antibacterial, antifungal, antiviral, and anti-biofilm properties of limonene may help it to be used in the future as a potential antimicrobial agent with minimal adverse effects. Some of the recent studies also showed the action of limonene against COVID-19 (Corona virus). However, additional studies are requisite to scrutinize the possible mechanism of antimicrobial action of limonene.
\end{abstract}

Keywords: Antibacterial, anti-biofilm, antifungal, antiviral, bioactive compound, limonene, COVID-19

*Correspondence: akshi.gupta.88@gmail.com; +91 7408656456

(Received: March 12, 2021; accepted: June 02, 2021)

Citation: Gupta A, Jeyakumar E, Lawrence R. Journey of Limonene as an Antimicrobial Agent. J Pure Appl Microbiol. 2021; 15(3):1094-1110. doi: 10.22207/JPAM.15.3.01

(C) The Author(s) 2021. Open Access. This article is distributed under the terms of the Creative Commons Attribution 4.0 International License which permits unrestricted use, sharing, distribution, and reproduction in any medium, provided you give appropriate credit to the original author(s) and the source, provide a link to the Creative Commons license, and indicate if changes were made. 


\section{INTRODUCTION}

Antibiotic resistance is emerging very rapidly because of the inappropriate or misuse of antimicrobials which is facilitated because of their accessibility over the counter, without prescription, and through unregulated delivery chains ${ }^{1}$. Antimicrobial agents also comprise adverse side effects along with microbial resistance. Hence, the interest of researchers is turned towards ethnopharmacology. Bioactive compounds are natural and ubiquitous in most plants and easily accessible to humans. Plant extracts provide immeasurable occasions for novel drug findings due to the exuberance of multifarious chemicals. Hence, thousands of obtainable medicinal phytochemicals are safe and more effective alternatives, for this reason, coupled with advancing microbial resistance to synthetic drugs; ethnopharmacology is swiftly gaining world acknowledgment ${ }^{2,3}$. In countries like Japan forest bathing trips are very popular and consider natural chemotherapy. Forest bathing trips include a trip to a forest for recreation and relaxation while breathing in volatile substances which are antimicrobial compounds derived from trees ${ }^{4}$. One of such components is limonene, which is one of the main constituents present in aromatic plants and the most common terpene present in nature. It is mainly found to be present in essential oils of peels of citrus spp. like lemon, orange, grapefruit, lime, and mandarin, etc. D-limonene is generally recognized as safe (GRAS) to be utilized as a flavoring agent. Due to its citrus fragrance, it is extensively used as a flavor and fragrance additive in soaps, perfumes, and chewing gums ${ }^{5}$. Limonene is also found to be present in many fruits, vegetables, meats, spices, and other food items ${ }^{6}$. Limonene is also popular for its various properties like antibacterial, antifungal, antiviral, and anti-biofilm. In the present study, the abovementioned properties of limonene discussed and proved experimentally in various studies are included and reviewed.

\section{What is Limonene?}

Limonene is also known by some other synonyms like D-(+)-limonene, (+)-limonene, (R)-limonene, (R)-(+)-limonene, cajeputene, carvene, cinene, (+)-dipentene, etc. The molecular formula of limonene is $\mathrm{C}_{10} \mathrm{H}_{16}$ and molecular weight is 136.24 . At room temperature limonene is a colorless liquid having lemon-like odor with a melting point temperature of $74.3^{\circ} \mathrm{C}$, boiling point temperature of $175.5-176^{\circ} \mathrm{C}$, and density of $0.8411 \mathrm{~g} / \mathrm{ml}$ (at $20^{\circ} \mathrm{C}$ ) and $0.8402 \mathrm{~g} / \mathrm{ml}$ (at $25^{\circ} \mathrm{C}$ ). It is slightly soluble in water $\left(13.8 \mathrm{mg} / \mathrm{L}\right.$ at $\left.25^{\circ} \mathrm{C}\right)$ and easily soluble in acetone, dimethyl sulfoxide, ethanol, benzene, carbon tetrachloride, diethyl ether, and petroleum ether. Limonene also gets oxidized when comes in contact with air and forms various oxidation products like carvone, limonene oxide, carveol, and limonene hydroperoxides hence it should be stored away from light and air. It is found to be present in peels of various citrus fruit species like orange, grape, lemon, and can be produced commercially from alkali treatment and steam distillation of citrus peel and pulp which remain after juice and cold-pressed oil production $^{7-10}$.

\section{Uses of Limonene}

Limonene is used as a flavor and fragrance additive in perfumes $(0.005 \%$ and $1 \%)$, soaps, beverages, food, and household cleaning products for nearly 50 years. It is also used in the formation of nonalcoholic beverages (31ppm), ice creams (68ppm), candy (49ppm), baked goods (120ppm), sweets, gelatin, puddings (48-400ppm), and chewing gums (2300ppm). In the petroleum industry, it has been used as solvent and cleaner, in the transdermal application of medicines it is used as an additive to increase the penetration of active substance, it is also used as a degreasing agent before the lacquering of industrial products $(30 \%)$, in the electronic industry for cleaning of printed circuits (50-100\%) and for cleaning print cylinders in printing work. Pesticide, insect repellent, and $\mathrm{dog} / \mathrm{cat}$ repellent are also well-known uses of limonene ${ }^{6,7,9,10}$.

\section{Antimicrobial activities of Limonene Antiviral}

Many viral diseases e.g. caused by Herpes simplex virus (HSV), influenza virus, and HIV are known as life-threatening. However various antiviral drugs against HIV, HSV, influenza, and other pathogenic viruses have been developed but the antecedence of these antiviral drugs is the potential and side effects of these drugs. There is still an urgent need for the development of new anti-viral agents which can fulfill all the drawbacks possessed by different antiviral drugs. Limonene can be used as a suitable anti-viral agent as some 
of the previous studies have emphasized its antiviral properties.

Anti-viral properties of limonene were studied against human pathogenic (Herpes simplex and influenza virus) as well as plant pathogenic viruses (tobacco mosaic virus). The anti-viral property of limonene against the Herpes simplex type 1 virus was found as complete inhibition of $\mathrm{HSV} 1$ at $25 \mu \mathrm{g} / \mathrm{ml}$ concentration of limonene was observed. Limonene inactivated the virus in the early phase of virus multiplication ${ }^{11}$. Cytotoxic concentration value $\left(\mathrm{CC}_{50}\right)$ of limonene at $1155 \mu \mathrm{g} /$ $\mathrm{ml}$ against HSV1 was also observed in another study ${ }^{12}$. Inhibition of the herpes simplex virus was observed by the formation of plaque on the kidney Vero cells ${ }^{13}$. On the other hand, the anti-viral property of Citrus delicios $a^{14}$ and Citrus reshni ${ }^{15}$ essential oils which contain limonene as the major component was also observed against the H5N1 virus. Anti-viral property of limonene against plant pathogenic virus, Tobacco mosaic virus (TMV) was also observed and it was found that TMV was inhibited by more than $45 \%$ after limonene treatment ${ }^{16}$.

Apart from influenza and other viruses limonene also identified as the inhibitor of the SARS corona virus as described in many studies. The SARS corona virus has protein $S$ a specific binding site for the angiotensin-converting enzyme 2 (ACE2) which serves as an entry point into the host cell. Limonene can act as the inhibitor for ACE2 target which is verified by performing docking studies ${ }^{17}$. Mechanism of action of herbal essential oils against viruses is either they coat the glycol proteins (potent of viral sites) of viruses or they bind with the human cell receptors (respiratory cells ACE- 2) which lead to the nonspecific and nonproductive binding of the virus particle to host cells which hinder the virus from infection. Some of the herbal essential oils which have antiviral or virucidal properties such as lavender oil, peppermint oil, and eucalyptus oil have limonene as the component ${ }^{18}$. ACE-2 inhibition property of limonene as a receptor for SARS-CoV-2 can prevent the invasion of SARS-CoV-2/COVID-19 into the human body ${ }^{19,20}$. Immunomodulatory, anti-inflammatory, and anti-viral properties of limonene can help limonene to limit the severity and succession of the COVID-19. Hence, limonene can act as a possible candidate against infection, immunity, and inflammation in COVID-1921. An oil blend was synthesized for the investigation of the effectiveness of the oil for the treatment in patients having COVID-19 like symptoms. The oil consisted of limonene as one of the chief components which provided anti-viral property to the oil. Limonene is known to restrain exclusively the viral DNA polymerase during the reproduction cycle when new viral DNA is synthesized. Hence, the oil was found as an effective remedial measure for COVID-1922. Limonene was also used for the quantitative evaluation of olfactory dysfunction in asymptomatic COVID-19 carriers $^{23}$.

\section{Antibacterial}

Antibacterial properties of limonene are well known and discussed in several reports against various bacterial species. Limonene is known to be active against many pathogenic bacteria involved in different diseases such as respiratory or skin diseases whereas some are known as contaminants causing contamination in the food industry. Synergistic activity of the combination of limonene enantiomers ( $D$ and $R$ ) and with other compounds has also been very well documented in many studies. Some of the studies have also highlighted the evaluation of chemical compositions of various essential oils from different plant materials and observed limonene as a major constituent and the reason for antibacterial activity shown by that essential oil. On the other hand, several methods were also reported in various studies to design nanoemulsions of limonene to be utilized in drug delivery, etc. Antibacterial actions of limonene against various bacterial species in various studies are summed up in Table 1.

Apart from the study on the antibacterial action of limonene, the mechanism of antibacterial action of limonene was also explained in some of the studies. A $\beta$-barrel protein (LptD) is an essential protein of the outer membrane present in lipopolysaccharide (LPS) assembly, depletion of this protein leads to the increase in membrane permeability of the bacterial cell. Attenuated total reflectance infrared microspectroscopy results after the treatment of $E$. coli cells with limonene showed the damage of LPS and altered outer membrane permeability was also observed in the study. It was concluded that the damage of LPS is the mechanism of inactivation by 


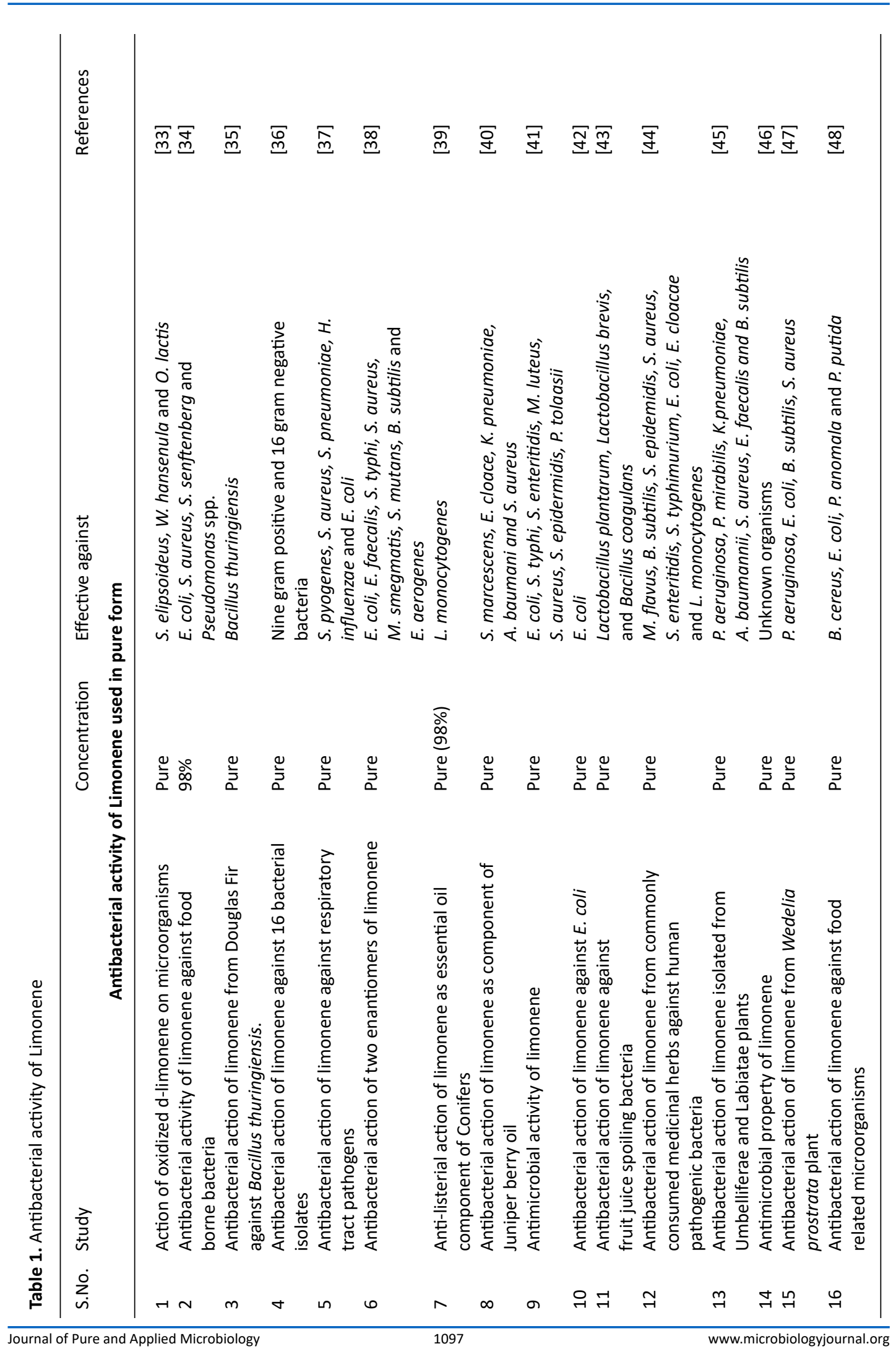




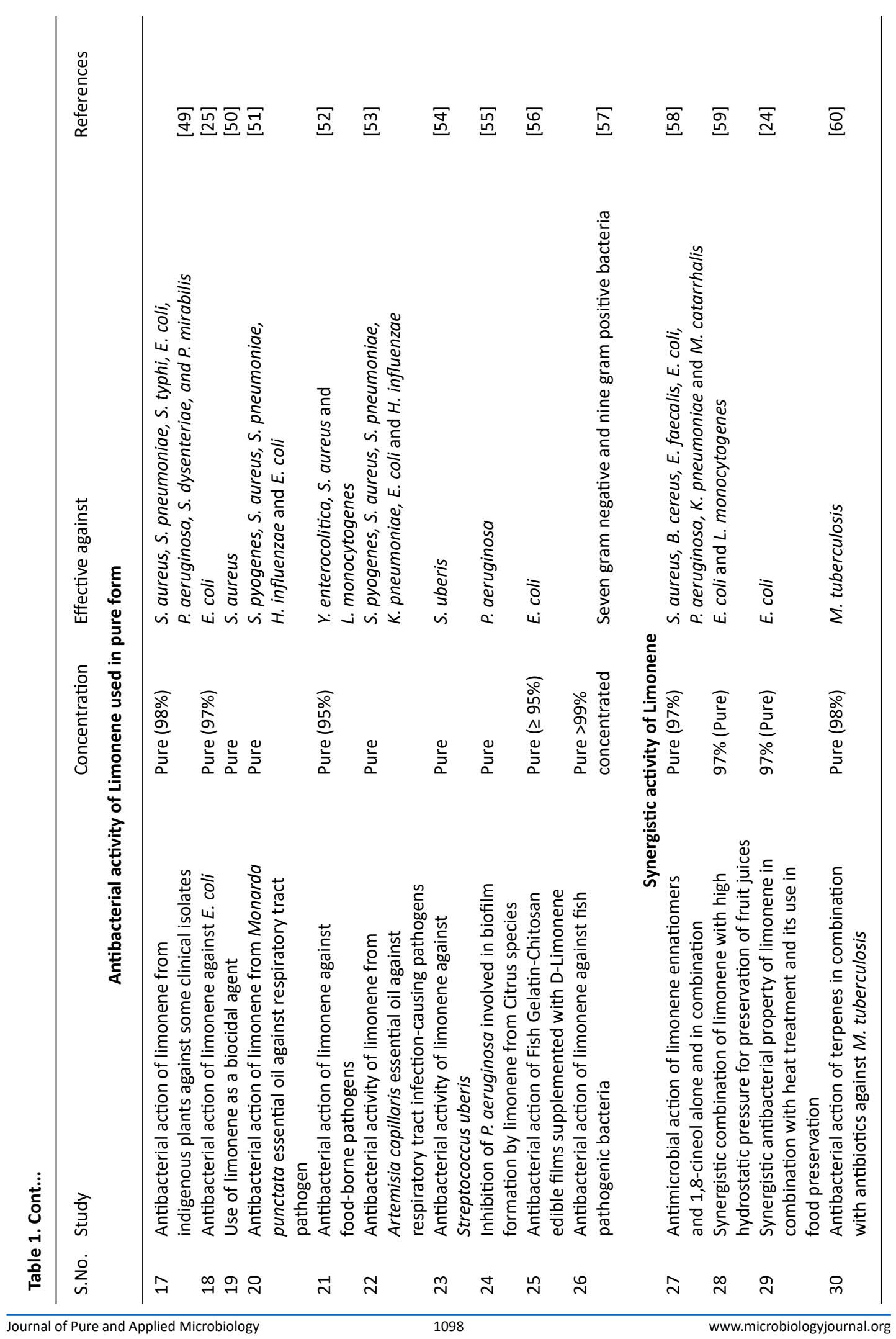




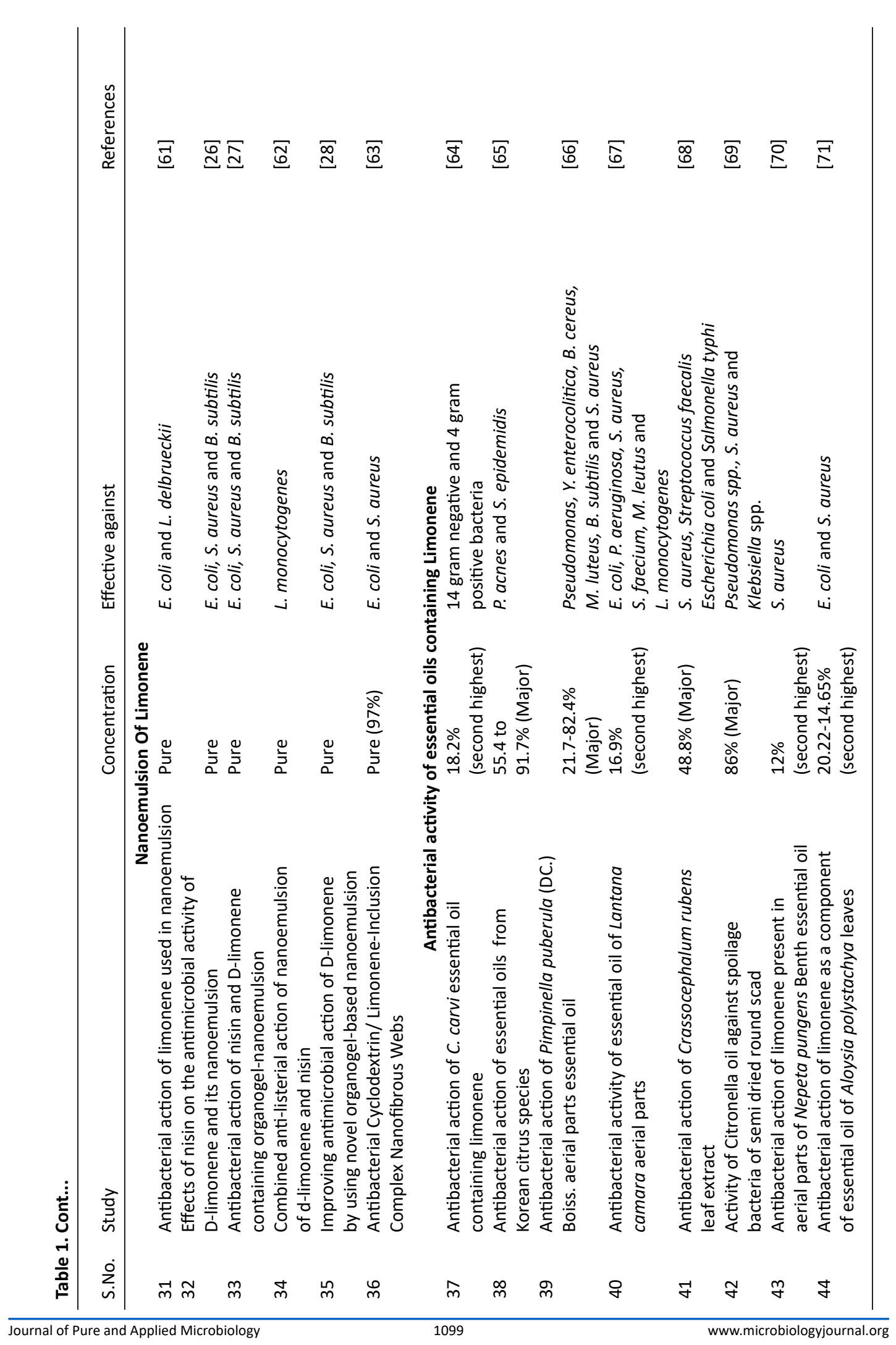




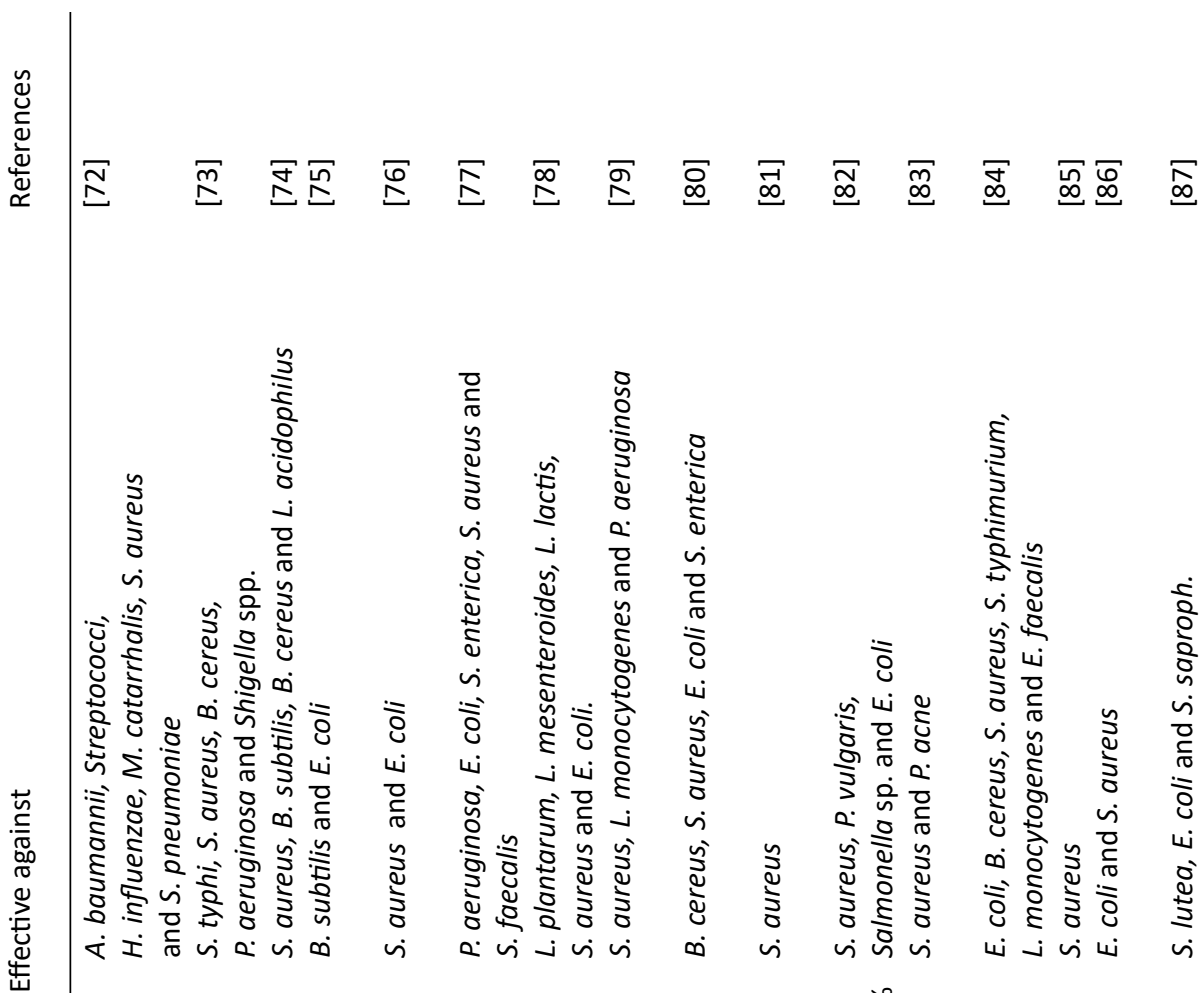

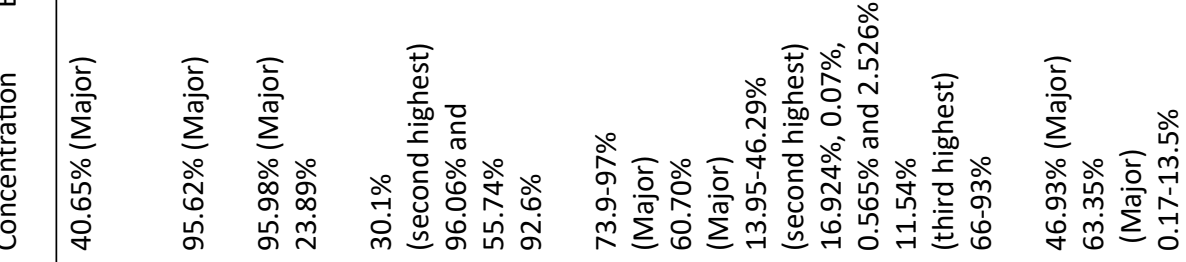

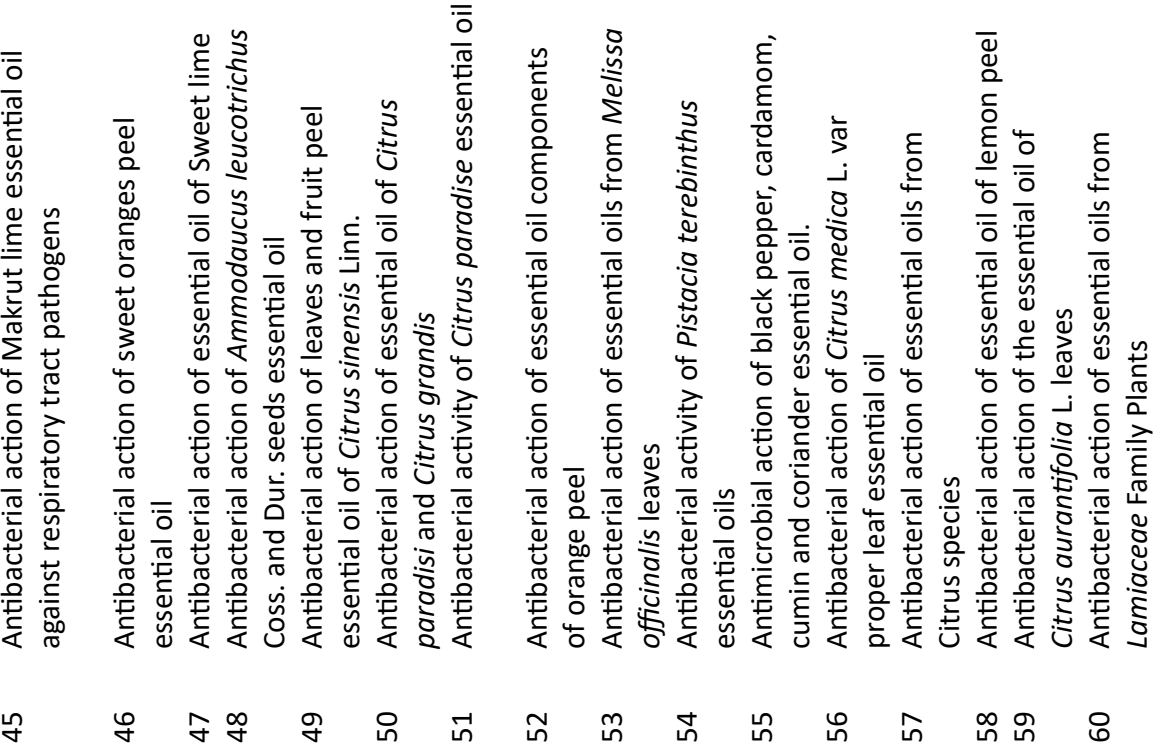


(+)-limonene and cell envelopes are the important target of limonene ${ }^{24}$. It was also explained that the mechanism of inactivation of $E$. coli cells by the treatment of limonene depends on the physiological state of the cell and the concentration of limonene. Exponentially growing $E$. coli cells were inactivated by limonene at the concentration of $2,000 \mu \mathrm{L} / \mathrm{L}$ and the mechanism of bacterial inactivation was observed to be the Fenton-mediated hydroxyl radical formation which leads to the oxidative DNA damage of the bacterial cell. On the other hand, $4,000 \mu \mathrm{L} / \mathrm{L}$ concentration of limonene caused a change in the membrane permeability of the cells and it was observed that at higher concentrations, inactivation of the bacterial cell is related to the altered membrane permeability ${ }^{25}$. Treatment of limonene nanoemulsion also showed the complete collapse of the cell structure which leads to the cell lysis and release of intracellular material from inside of the cell. The effect of limonene nano-emulsion was not only restricted to Gram-negative bacteria ( $E$. coli) but a similar effect was also observed with Gram-positive isolates (B. subtilis and S. aureus) ${ }^{26}$. A similar effect of limonene nano-emulsion was also observed as limonene nano-emulsion altered the cell membranes of $E$. coli, S. aureus, and $B$. subtilis which lead to the outflow of intracellular substances from the treated bacterial cells of all three isolates ${ }^{27}$. Moreover, deformed and incomplete shapes of the bacterial cells ( $E$. coli, $S$. aureus, and $B$. subtilis) were also scrutinized by scanning electron microscopy due to an increase in the permeabilization of the cells which leads to disruption of membrane integrity by the treatment of limonene nano-emulsion ${ }^{28}$.

It is evident by above-mentioned studies that limonene causes damage to the cell membrane of Gram-positive as well as Gramnegative bacterial cells which initiates the leakage of intracellular materials and ultimately leads to cell death. However, the efficacy of limonene or any other antibacterial agent may differ in Grampositive and Gram-negative cells. The cytoplasmic membrane is known as the primary target in Grampositive bacterial cells while in Gram-negative bacteria outer membrane is known as the primary target for antibacterial agents ${ }^{29}$. Gram-negative cells are more efficient than Gram-positive bacterial cells in maintaining their membrane homeostasis, which is why there is a difference between antimicrobial agents towards the bactericidal activity ${ }^{30}$. It was also explained that the outer membrane of Gram-negative bacteria, which is composed of lipopolysaccharide molecules establishs a hydrophilic permeability barrier that protects against the effect of highly hydrophobic drugs $^{31}$. This also explains the reason for the low sensitivity of Gram-negative bacterial cells to the lethal effects of lipophilic monoterpenes like limonene.

Most of the studies mentioned aboveobserved cell membrane damage and alteration in the membrane permeability as the mechanism of action of limonene. However, the precise mechanism of limonene as an antibacterial drug is largely unknown as the series of events which leads to the cell death by the action of limonene are not studied. In a recent study, the effects of limonene on protein expressions related to respiratory chain complex in L. monocytogenes were studied. Limonene treatment to bacterial cells was observed to down-regulate different respiratory chain-related complexes ${ }^{32}$. Moreover, additional studies are required to decipher the exact molecular mechanisms of limonene against various other pathogenic Gram-positive or Gramnegative bacteria.

\section{Antifungal}

Limonene is also known for its antifungal properties. It has been observed that limonene is effective against various yeasts and molds which are known as the major contaminant of food products (pudding), dairy (yogurt, cheese, and dairy caramels), fruits (Wine grapes, satsumas, apples, strawberries), grains (wheat flour, corn, peanuts, coffee, cocoa powder, cereal), flavored water and chocolate ${ }^{88}$. Some of the yeasts are known to cause contamination in other food products such as meat, vegetables, nonalcoholic beverages, alcoholic beverages, and bakery products $^{89}$. While some of the fungal species are known to be pathogenic to humans. Antifungal properties of limonene have been explored against various fungal species. Various antifungal properties of limonene are summarized in Table 2.

The antifungal mechanism of action of limonene was also studied against few fungal isolates. Treatment of limonene to yeast cells arise 


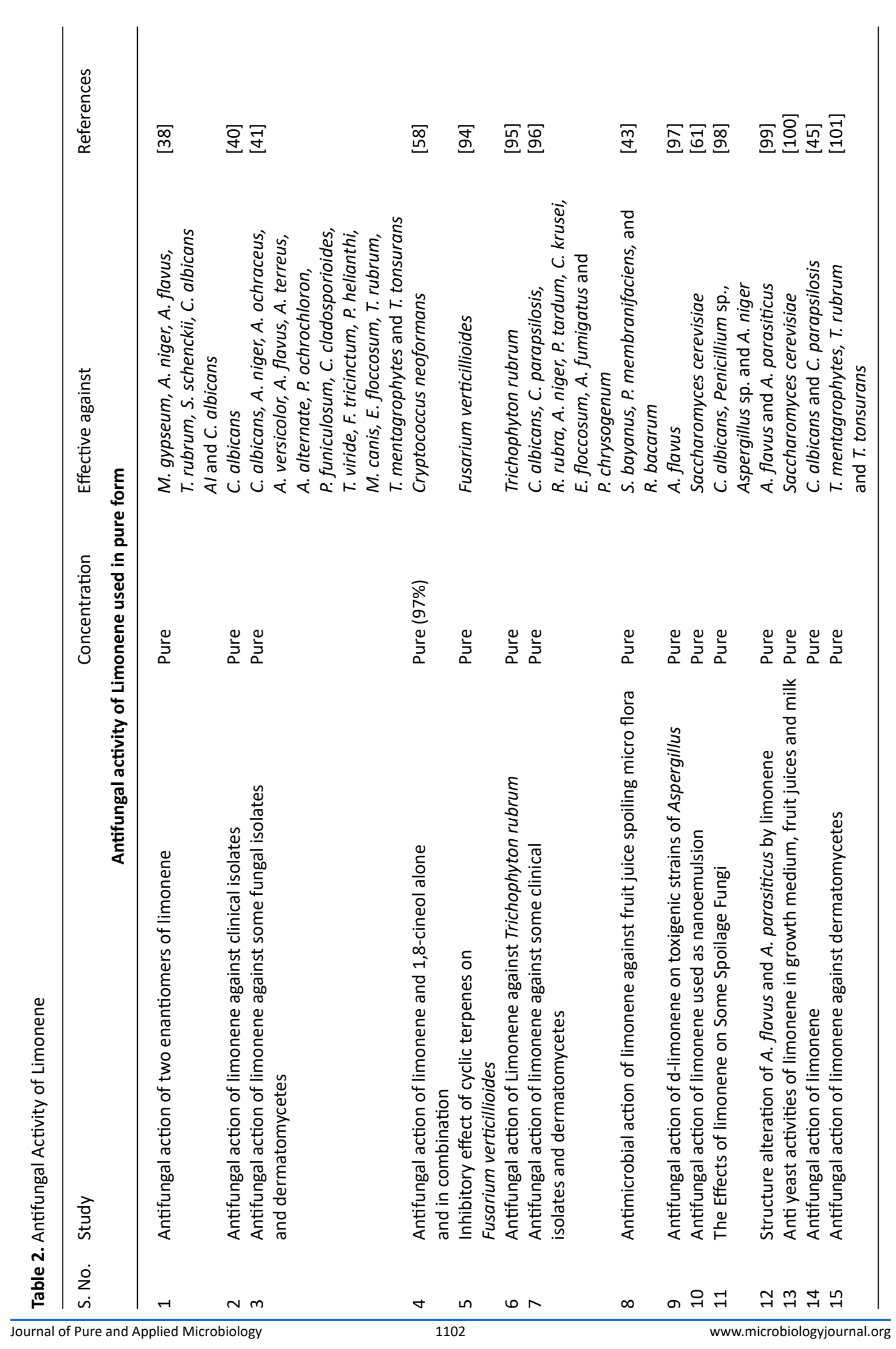




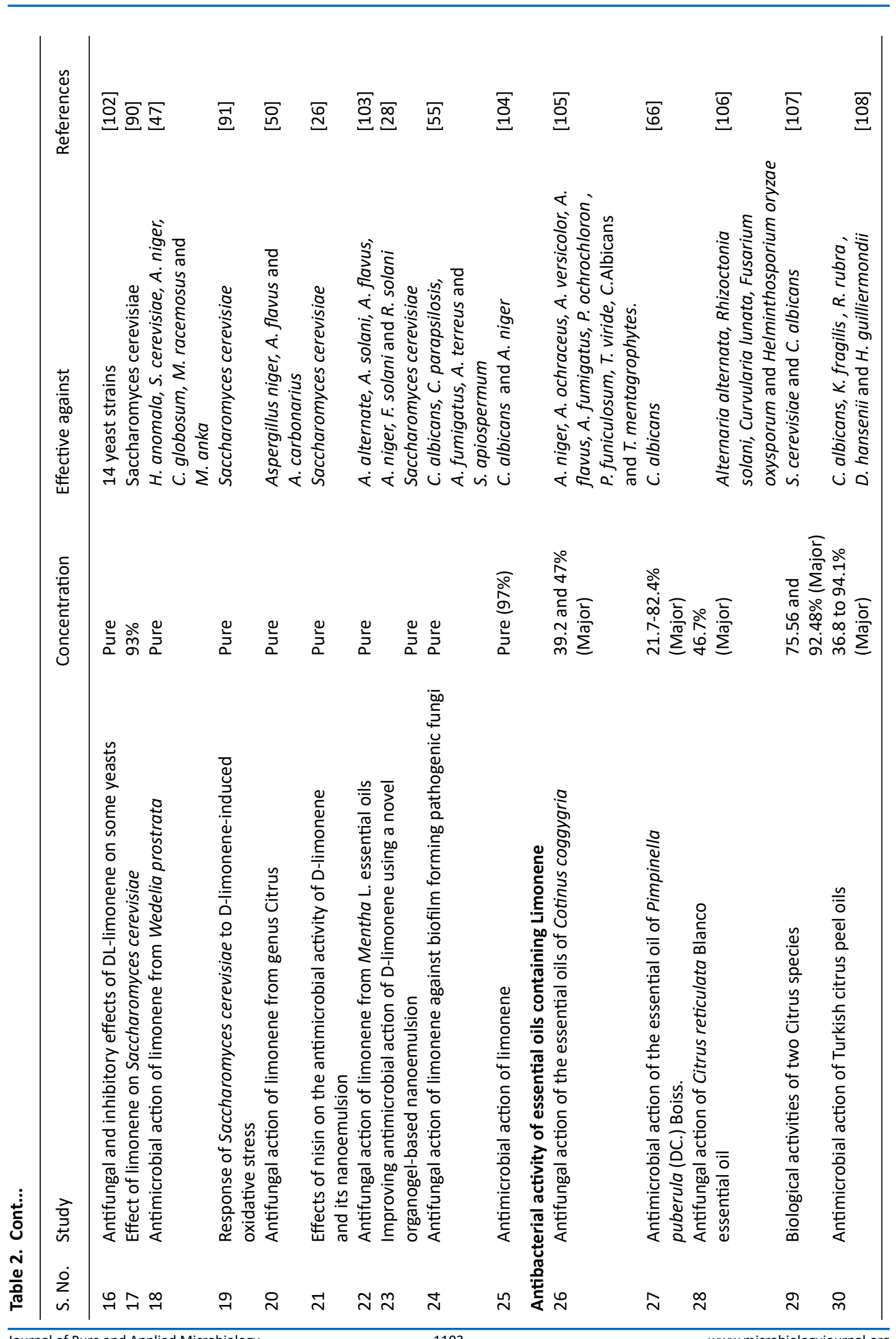




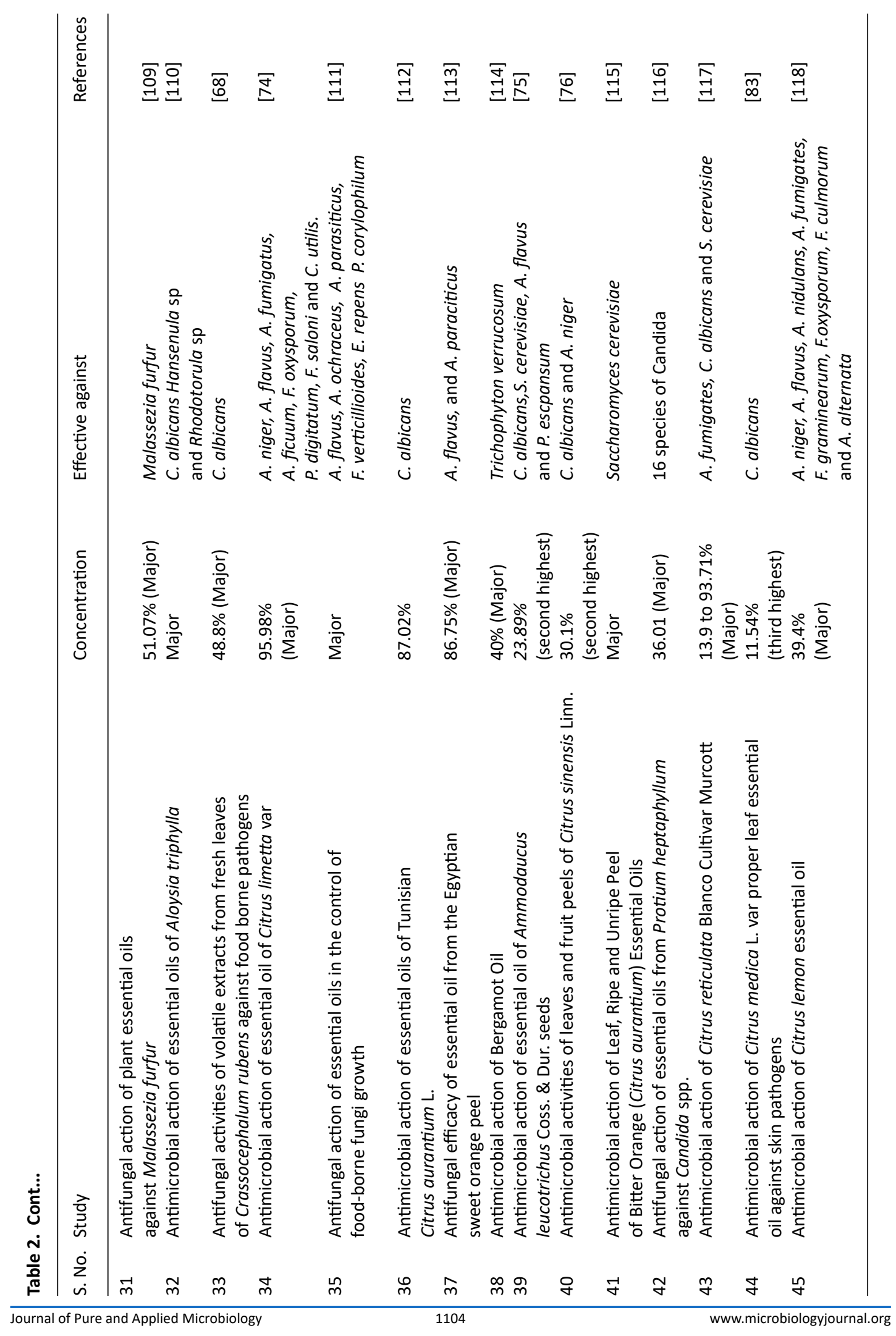


a compensatory response in the form of overexpression of various genes (i.e., ROM1, RLM1, PIR3, CTT1, YGP1, MLP1, PST1, CWP1) which are involved in cell wall integrity signaling pathway. It was concluded that limonene treatment leads to cell wall deterioration in the yeast cells. The fact of alteration in structure and function of yeast which further affects the cytokinesis due to limonene was established ${ }^{90}$. Limonene was also observed to induce the accumulation of reactive oxygen species (ROS) in fungal isolates and leads to cell death $^{91}$. Scanning electron microscopic analysis of fungal isolates after the treatment of limonene showed the deformation and distortion of the fungal cells which further leads to the leakage of intracellular material due to damaged cell membrane ${ }^{26,28}$. Mechanism of antifungal action of limonene was also studied against Candida albicans in which treatment of limonene cause alteration in membrane permeabilization of up to $82-88 \%$ of the cells ${ }^{55}$. Mechanism of action of limonene against Candida sp. involved in intravaginal infections was also examined. Results of the study showed the protective role of limonene against Vulvovaginal candidiasis causing fungal isolates, as a low fungal burden in mice was observed after the treatment with limonene in comparison to untreated mice. Electron microscopy also revealed that limonene treatment caused dramatic structural changes in fungal cells including cell wall rupture ${ }^{92}$. Limonene is also found to inhibit the intracellular and extracellular enzymes such as cellulase and pectin methyl esterase present in some fungal isolates such as $A$. niger, $P$. digitatum, F. oxysporium and $R$. solani $i^{93}$.

All the above-mentioned studies explained a few of the antifungal mechanisms of action of limonene against various fungal isolates. However, exact mechanisms of the antifungal actions of limonene are not yet unrevealed hence; further studies are required to explore the antifungal mechanisms of limonene.

\section{Anti-biofilm production property of Limonene}

Resistance in microorganisms against various antimicrobial agents has become the main concern in the medical industry nowadays. The formation of biofilm by microorganisms is one of the mechanisms to acquire resistance against antimicrobial agents. Hence, it is important to find alternative therapeutic agents with anti-biofilm properties. Many plant-based compounds are being examined for their therapeutic properties of which only a few are reported to exhibit antibiofilm activity ${ }^{119}$. Limonene is one the plant-based compounds which possess anti-biofilm property. The anti-biofilm property of limonene is also investigated and proved in various studies by many researchers. The anti-biofilm property of limonene was examined against B. cereus, E. coli, P. anomala and $P$. putida and significant inhibition of biofilm of $B$. cereus, $E$. coli, and $P$. anomala by limonene was observed $^{48}$. About 75-95\% biofilm inhibition was observed against S. pyogenes, S. mutans, and S. mitis at $400 \mu \mathrm{g} / \mathrm{ml}$ concentration of limonene ${ }^{120}$. Limonene was also found to reduce the biofilm mass production up to $90 \%$ after 8 h of incubation at the concentration of $2000 \mu \mathrm{l} / \mathrm{L}$ in different strains of $S$. aureus ${ }^{121}$. In another study, effective biofilm inhibition by limonene against $P$. aeruginosa, $C$. albicans, and C. parapsilosis was also observed ${ }^{55}$. In silico determination of anti-biofilm property of limonene against $S$. mutans showed that limonene can act as a good candidate for the inhibition of development in biofilm formation ${ }^{122}$.

\section{Concluding Remarks and Future Perspectives}

As discussed above, limonene possesses antimicrobial properties such as antibacterial, antifungal, and antiviral. Limonene was also found to hinder biofilm formation and most importantly limonene also shows the inhibitory action against COVID-19. Limonene is suggested to be safe as it is derived from natural sources e.g. citrus plants. Hence, the use of limonene in the future for therapeutic purposes in clinical settings may be considered. Moreover, researches on combinatorial studies of limonene with other drugs are also inevitable to achieve better outcomes in breaking the therapeutic resistance of microbes. Delineation of the mechanistic approach of limonene towards antimicrobial activities is also desirable. Therefore, it may be suggested that there is still a wide lacuna of knowledge to be acquired to venture limonene as a future potential drug molecule.

\section{ACKNOWLEDGMENTS}

The authors gratefully acknowledge the support extended by Sam Higginbottom University of Agriculture, Technology and Sciences, Prayagraj, towards this piece of work. 


\section{CONFLICT OF INTEREST}

The authors declare that there is no conflict of interest.

\section{AUTHORS' CONTRIBUTION}

All authors listed have made a substantial, direct and intellectual contribution to the work, and approved it for publication.

\section{FUNDING}

None.

\section{DATA AVAILABILITY}

The datasets generated during and/or analyzed during the current study are available from the corresponding author on reasonable request.

\section{ETHICS STATEMENT}

Not applicable.

\section{REFERENCES}

1. Ayukekbong JA, Ntemgwa M, Atabe AN. The threat of antimicrobial resistance in developing countries: causes and control strategies. Antimicrob Resist Infect Control. 2017;6:47. doi: 10.1186/s13756-017-0208-x

2. Sasidharan S, Chen Y, Saravanan D, Sundram KM, Latha LY. Extraction, isolation and characterization of bioactive compounds from plant extracts. Afr J Tradit Complement Altern Med. 2011;8(1):1-10. doi: 10.4314/ajtcam.v8i1.60483

3. Achilonu MC, Umesiobi DO. Bioactive phytochemicals: bioactivity, sources, preparations, and/or modifications via silver tetrafluoroborate mediation. J Chem. 2015;2015:629085. doi: 10.1155/2015/629085

4. Li Q. Effect of forest bathing trips on human immune function. Environ Health Prev Med. 2010;15(1):9-17. doi: 10.1007/s12199-008-0068-3

5. Sun J. D-limonene: safety and clinical applications. Altern Med Rev. 2007;12(3):259-264.

6. United States Environmental Protection Agency. Prevention pesticides and toxic substances (7508W). Reregistration Eligibility Decision (RED). EPA 738-R-94034, September, 1994.

7. IARC monograph. Some naturally occurring substances: Food items and constituents, heterocyclic aromatic amines and mycotoxins. D-limonene. 1993;56.

8. IARC monograph. Some chemicals that cause tumours of the kidney or urinary bladder in rodents and some other substances. D-limonene. 1999;73.

9. Danish ministry of the environment, Environmental protection agency. Evaluation of health hazards by exposure to d-limonene and proposal of a health based quality criterion for ambient air. 2013.

10. National toxicological program technical report series No. 347. Toxicology and carcinogenesis studies of $\mathrm{d}$-limonene in $\mathrm{F} 344 / \mathrm{N}$ rats and B6C3F1 mice. U.S. department of health and human services. Public health service. National institutes of health. January 1990.

11. Astani A, Schnitzler P. Antiviral activity of monoterpenes beta-pinene and limonene against herpes simplex virus in vitro. Iran J Microbiol. 2014;6(3):149-155.

12. Vogt MV, Sutil SB, Escobar FM, et al. Minthostachys verticillata essentials oil and its major components: anti herpetic selective action in HEp-2 cells. Mol Med Chem. 2010;21:117-120.

13. Franchomme P. Pharmacology of R (+)-Limonene and some citrus peel essences. Proceedings of the 4th Aromatherapy Conference on the therapeutic uses of essential oils. San Francisco, 2000.

14. El-hawary SS, Taha KF, Abdel-Monem AR, Kirillos FN, Mohamed AA. Chemical composition and biological activities of peels and leaves essential oils of four cultivars of Citrus deliciosa Var. tangarina. Am J Essent Oil Nat Prod. 2013;1(2):1-6.

15. Nagy MM, Al-Mahdy DA, Aziz OMAE, Kandil AM, Tantawy MA, Alfy TSME. Chemical composition and antiviral activity of essential oils from Citrus reshni hort. Ex Tanaka (Cleopatra mandarin) cultivated in Egypt. J Essent Oil Bear Plants. 2018;21(1):264-272. doi: 10.1080/0972060X.2018.1436986

16. Min L, Han $Z, X u Y$, Yao L. In vitro and In vivo anti Tobacco mosaic virus activities of essential oils and individual compounds. J Microbiol Biotechnol. 2013;23(6):771-778. doi: 10.4014/jmb.1210.10078

17. Abdelli I, Hassani F, Brikci SB, Ghalem S. In silico study the inhibition of angiotensin converting enzyme 2 receptor of COVID-19 by Ammoides verticillata components harvested from Western Algeria. J Biomol Struct Dyn. 2021;39(9):3263-3276. doi: 10.1080/07391102.2020.1763199

18. Al-garawyi AMA, Hussein TA, Jassim MMA. Inhibition of viral infection by using of natural herbal remedies as alternative treatment. Sys Rev Pharm. 2020;11(6):416419. doi: $10.31838 /$ srp.2020.6.66

19. Khan ZA. Preventive role of mouthwashes in COVID-19 disease transmission: An overview. Asian J Oral Health Allied Sci. 2020;10(9):1-5. doi: 10.25259/ AJOHAS_14_2020

20. Kumar KJS, Vani MG, Wang CS, et al. Geranium and lemon essential oils and their active compounds downregulate angiotensin-converting enzyme 2 (ACE2), a SARS-CoV-2 spike receptor-binding domain, in epithelial cells. Plants. 2020;9(6):770. doi: 10.3390/ plants9060770

21. Meeran MFN, Seenipandi A, Javed H, et al. Can limonene be a possible candidate for evaluation as an agent or adjuvant against infection, immunity, and inflammation in COVID-19? Heliyon. 2020;7(1):e05703. doi: 10.1016/j.heliyon.2020.e05703

22. Bahl AS. Effectiveness of polyherbal topical oil treatment for patients either with 'COVID-19 like symptoms or 'COVID-19 Positive': A prospective study. Insights In Biomed. 2020;5(4):1-10. doi: 10.36648/2572-5610.4.4.77

23. Bhattacharjee AS, Joshi SV, Naik S, Sangle S, Abraham NM. Quantitative assessment of olfactory dysfunction accurately detects asymptomatic COVID-19 carriers. 
E. Clinical Medicine. 2020;28:100575. doi: 10.1016/j. eclinm.2020.100575

24. Espina L, Gelaw TK, Castellvi SDL, Pagan R, Gonzalo DG. Mechanism of bacterial inactivation by (+)-Limonene and its potential use in food preservation combined processes. PLoS One. 2013;8(2):e56769. doi: 10.1371/ journal.pone.0056769

25. Chueca B, Pagan R, Gonzalo DG. Differential mechanism of Escherichia coli inactivation by (+) Limonene as a function of cell physiological state and drug's concentration. PLoS One. 2014;9(4):e94072. doi: 10.1371/journal.pone.0094072

26. Zhang Z, Vriesekoop F, Yuan Q, Liang H. Effects of nisin on the antimicrobial activity of D-limonene and its nanoemulsion. Food Chem. 2014;150:307-312. doi: 10.1016/j.foodchem.2013.10.160

27. Bei $W$, Zhou $Y$, Xing $X$, et al. Organogel-nanoemulsion containing nisin and D-limonene and its antimicrobial activity. Front Microbiol. 2015;6:1010. doi: 10.3389/ fmicb.2015.01010

28. Zahi MR, Liang H, Yuan Q. Improving the antimicrobial activity of D-limonene using a novel organogel based nanoemulsion. Food Control. 2015;50:554-559. doi: 10.1016/j.foodcont.2014.10.001

29. Li J, Ahn J, Liu D, Chen S, Ye X, Ding T. Evaluation of ultrasound-induced damage to Escherichia coli and Staphylococcus aureus by flow cytometry and transmission electron microscopy. Appl Env Microbio. 2016;82(6):1828-1837. doi: 10.1128/AEM.03080-15

30. Sani MA, Henriques ST, Weber D, Separovic. Bacteria may cope differently from similar membrane damage caused by the Australian tree frog antimicrobial peptide maculatin 1.1. J Biol Chem. 2015;290(32):1985319862. doi: 10.1074/jbc.M115.643262

31. Trombetta D, Casteelli F, Sarpietro MG, et al. Mechanisms of antibacterial action of three monoterpenes. Antimicrob Agents Chemother. 2005;49(6):2474-2478. doi: 10.1128/AAC.49.6.24742478.2005

32. Han Y, Sun Z, Chen W. Antimicrobial susceptibility and antibacterial mechanism of limonene against Listeria monocytogenes. Molecules. 2019;25(1):33. doi: $10.3390 /$ molecules 25010033

33. Zukerman I. Effect of oxidized d-limonene on microorganisms. Nature. 1951;168:517. doi: 10.1038/168517a0

34. Dabbah R, Edwards VM, Moats WA. Antimicrobial action of some citrus fruit oils on selected food borne bacteria. Appl Microbiol. 1970;19(1):27-31. doi: 10.1128/AM.19.1.27-31.1970

35. Andrews RE, Parks LW, Spence KD. Some effects of Douglas Fir terpenes on certain microorganisms. Appl Environ Microbiol. 1980;40(2):301-304. doi: 10.1128/ aem.40.2.301-304.1980

36. Dorman HJD, Deans SG. Antimicrobial agents from plants: antibacterial activity of plant volatile oils. J Appl Microbiol. 2000;88(2):308-316. doi: 10.1046/j.13652672.2000.00969.x

37. Inouye S, Takizawa T, Yamaguchi. Antibacterial activity of essential oils and their major constituents against respiratory tract pathogens by gaseous contact. J Antimicrob Chemother. 2001;47(5):565-573. doi: 10.1093/jac/47.5.565

38. Aggarwal KK, Khanuja SPS, Ahmad A, Kumar TRS, Gupta VK, Kumar S. Antimicrobial activity profiles of the two enantiomers of limonene and carvone isolated from the oils of Mentha spicata and Anethum sowa. Flavour Fragr J. 2002;17(1):59-63. doi: 10.1002/ffj.1040

39. Mourey A, Canillac N. Anti-Listeria monocytogenes activity of essential oils components of Conifers. Food Control. 2002;13(4-5):289-292. doi: 10.1016/S09567135(02)00026-9

40. Filipowicz N, Kaminski M, Kurlenda J, Asztemborska $M$, Ochocka JR. Antibacterial and antifungal activity of Juniper berry oil and its selected components. Phytother Res. 2003;17(3):227-231. doi: 10.1002/ ptr.1110

41. Rancic A, Sokovic M, Griensven LV, Vukojevic J, Brkic D, Ristic MS. Antimicrobial activity of limonene. $Z b$ Rad. 2003;23(23):83-88.

42. Nannapaneni R, Muthaiyan A, Crandall PG, et al. Antimicrobial activity of commercial citrus-based natural extracts against Escherichia coli 0157:H7 isolates and mutant strains. Food borne Pathog Dis. 2008;5(5):695-699. doi: 10.1089/fpd.2008.0124

43. Bevilacqua $A$, Corbo $M R$, Sinigaglia $M$. In vitro evaluation of the antimicrobial activity of eugenol, limonene, and citrus extract against bacteria and yeasts, representative of the spoiling micro flora of fruit juices. J Food Prot. 2010;73(5):888-894. doi: 10.4315/0362-028x-73.5.888

44. Sokovic M, Glamoclija J, Marin PD, Brkic D, Van Griensven LJLD. Antibacterial effects of the essential oils of commonly consumed medicinal herbs using an in vitro model. Molecules. 2010;15(11):7532-7546. doi: 10.3390/molecules 15117532

45. Orhan IE, Ozcelik B, Kartal M, Kan Y. Antimicrobial and antiviral effects of essential oils from selected umbelliferae and Labiattae plants and individual essential oil components. Turk J Biol. 2012;36(3):239246. doi: 10.3906/biy-0912-30

46. Azarakhsh N, Osman A, Ghazali HM, Tan CP, Adzahan NM. Effect of limonene incorporation into Gellan based edible coating on the changes in microbiological and sensory characteristics of fresh cut pineapple during cold storage. Acta Hortic. 2013;1012:999-1004. doi: 10.17660/actahortic.2013.1012.134

47. Dai J, Zhu L, Yang L, Qui J. Chemical composition, antioxidant and antimicrobial activities of essential oil from Wedelia prostrata. EXCLI Journal. 2013;12:479490. doi: 10.17877/DE290R-7125

48. Kerekes EB, Deak E, Tako M, et al. Anti-biofilm forming and anti-quorum sensing activity of selected essential oils and their main components on food related microorganisms. J Appl Microbiol. 2013;115(4):933942. doi: 10.1111/jam.12289

49. Vimal M, Vijaya PP, Mumtaj P, Farhath MSS. Antibacterial activity of selected compounds of essential oils from indigenous plants. J Chem Pharm Res. 2013;5(1):248-253.

50. Gomes MS, Cardoso MDG, Soares MJ, et al. Use of essential oils of the Genus Citrus as biocidal agent. Am J Plant Sci. 2014;5(3):299-305. doi: 10.4236/ ajps.2014.53041 
51. Li H, Yang T, Li FY, Yao Y, Sun ZM. Antibacterial activity and mechanism of action of Monarda punctata essential oil and its main components against common bacterial pathogens in respiratory tract. Int J Clin Exp Pathol. 2014;7(11):7389-7398.

52. Haiyan LU, Chongxin XU, Xiao Z, Ying L, Xianjin LIU. Antibacterial effect of limonene on food-borne pathogens. J Zhejiang Univ. 2016;42(3):306-312. doi: 10.3785/j.issn.1008-9209.2015.07.141

53. Yang C, Hu DH, Feng Y. Antibacterial activity and mode of action of the Artemisia capillaris essential oil and its constituents against respiratory tract infection-causing pathogens. Mol Med Rep. 2015;11(4):2852-2860. doi: 10.3892/mmr.2014.3103

54. Montironi ID, Cariddi LN, Reinoso EB. Evaluation of the antimicrobial efficacy of Minthostachys verticillata essential oil and limonene against Streptococcus uberis strains isolated from bovine mastitis. Rev Argent Microbiol. 2016;48(3):210-216. doi: 10.1016/j. ram.2016.04.005

55. Pekmezovic M, Aleksic I, Barac A, et al. Prevention of poly microbial biofilms composed of Pseudomonas aeruginosa and pathogenic fungi by essential oils from selected Citrus species. Pathog Dis. 2016;74(8):1-10. doi: $10.1093 / \mathrm{femspd} / \mathrm{ftw} 102$

56. Yao $Y$, Ding D, Shao H, Peng Q, Huang Y. Antibacterial activity and physical properties of fish gelatin-chitosan edible films supplemented with D-limonene. Int J Polym Sci. 2017;1837171. doi: 10.1155/2017/1837171

57. Pathirana HNKS, Wimalasena SHMP, Silva BCJD, Hossain S, Heo GJ. Antibacterial activity of lime (Citrus aurantifolia) essential oil and limonene against fish pathogenic bacteria isolated from cultured olive flounder (Paralichthys olivaceus). Fish Aquat Life. 2018;26(2):131-139. doi: 10.2478/aopf-2018-0014

58. Vuuren SF, Viljoen AM. Antimicrobial activity of limonene enantiomers and 1,8-cineole alone and in combination. Flavour Fragr J. 2007;22(6):540-544. doi: 10.1002/ffj.1843

59. Espina L, Garcia-Gonzalo D, Laglaoui A, Mackey BM, Pagan R. Synergistic combinations of high hydrostatic pressure and essential oils or their constituents and their use in preservation of fruit juices. Int J Food Microbiol. 2013;161(1):23-30. doi: 10.1016/j. ijfoodmicro.2012.11.015

60. Sieniawska E, Ossor MS, Sawicki R, Wozniak KS, Ginalska G. Natural terpenes influence the activity of antibiotics against isolated Mycobacterium tuberculosis. Med Princ Pract. 2017;26(2):108-112. doi: 10.1159/000454680

61. Donsi F, Annunziata M, Sessa M, Ferrari G. Nano encapsulation of essential oils to enhance their antimicrobial activity in foods. LWT- Food Sci Technol. 2011;44(9):1908-1914. doi: 10.1016/j.lwt.2011.03.003

62. Mate J, Periago PM, Palop A. Combined effect of a nanoemulsion of D-limonene and nisin on Listeria monocytogenes growth and viability in culture media and foods. Food Sci Technol Int. 2015;22(2):146-152. doi: 10.1177/1082013215577034

63. Aytac Z, Yildiz ZI, Senirmak FK, et al. Fast-Dissolving, prolonged release and antibacterial cyclodextrin/ limonene-inclusion complex nanofibrous webs via polymer free electrospinning. J Agric Food Chem. 2016;64(39):7325-7334. doi: 10.1021/acs. jafc.6b02632

64. lacobellis NS, Cantore PL, Capasso F, Senatore F. Antibacterial activity of Cuminum cyminum L. and Carum carvi L. essential oils. J Agric Food Chem. 2005;53(1):57-61. doi: 10.1021/jf0487351

65. Baik JS, Kim SS, Lee JA, et al. Chemical compositions and biological activities of essential oils extracted from Korean endemic Citrus species. J Microbiol Biotechnol. 2008;18(1):74-79.

66. Askari F, Sefidkon F, Teimouri M, Nanaei SY. Chemical composition and antimicrobial activity of the essential oil of Pimpinella puberula (DC.) Boiss. J Agric Sci Technol. 2009;11(4):431-438.

67. Benites J, Moiteiro C, Miguel G, et al. Composition and biological activity of the essential oil of Peruvian Lantana camara. J Chil Chem Soc. 2009;54(4):379-384. doi: 10.4067/s0717-97072009000400012

68. Yehouenou B, Wotto V, Bankole H, Sessou P, Noudogbessi JP, Sohounhloue D. Chemical study and antimicrobial activities of volatile extracts from fresh leaves of Crassocephalum rubens (Juss and Jack) S. moore against food borne pathogens. Scientific Study and Research: Chemistry and Chemical Engineering, Biotechnology, Food Industry. 2010;11(3):343-351.

69. Jaroenkit $P$, Matan $N$, Nisoa $M$. In vitro and in vivo activity of Citronella oil for control of spoilage bacteria of semi dried round scad (Decapterus maruadsi). Int J Med Aromatic Plants. 2011;1(3):234-239.

70. Farjam MH. Antibacterial activity and composition of essential oil of Nepeta pungens Benth Iran. J Appl Pharm Sci. 2012;2(4):103-105. doi: 10.7324/ JAPS.2012.2415

71. Pina ES, Coppede JDS, Sartoratto A, et al. Antimicrobial activity and chemical composition of essential oils from Aloysia polystachya (Griseb.) Moldenke grown in Brazil. J Med Plants Res. 2012;6(41):5412-5416. doi: 10.5897/JMPR11.276

72. Srisukh V, Tribuddharat C, Nukoolkarn V, et al. Antibacterial activity of essential oils from Citrus hystrix (makrut lime) against respiratory tract pathogens. Sci Asia. 2012;38(2):212. doi: 10.2306/ scienceasia1513-1874.2012.38.212

73. Ullah N, Amin M, Ali J, et al. Chemical composition and antimicrobial activity evaluation of Sweet Oranges (Citrus cinenses) peels essential oil. J Pharm Res. 2012;5(3):1698-1700.

74. Javed S, Ahmad R, Shahzad K, Nawaz S, Saeed S, Saleem Y. Chemical constituents, antimicrobial and antioxidant activity of essential oil of Citrus limetta var. Mitha (Sweet lime) peel in Pakistan. Afr J Microbiol Res. 2013;7(24):3071-3077. doi: 10.5897/AJMR12.1254

75. Louail Z, Kameli A, Benabdelkader T, Bouti K, Hamza $\mathrm{K}$, Krimat S. Antimicrobial and antioxidant activity of essential oil of Ammodaucus leucotrichus Coss. and Dur. seeds. J Mater Environ Sci. 2018;7(7):2328-2334.

76. Singh V, Katiyar D, Ali M. Comparative study of volatile constituents and antimicrobial activities of leaves and fruit peels of Citrus sinensis Linn. J Pytopharmacol. 2015;4(2):102-105.

77. Ou MC, Liu YH, Sun YW, Chan CF. The composition, 
antioxidant and antibacterial activities of cold-pressed and distilled essential oils of Citrus paradisi and Citrus grandis L. Osbeck. Evid Based Complement Alternat Med. 2015;2015:804091. doi: 10.1155/2015/804091

78. Vasek OM, Caceres LM, Chamorro ER, Velasco GA. Antibacterial activity of Citrus paradisi essential oil. J Nat Prod. 2015;8:16-26.

79. Geraci A, Stefano VD, Martino ED, Schillaci D, Schicchi R. Essential oil components of orange peels and antimicrobial activity. Nat Prod Res. 2017;31(6):653659. doi: $10.1080 / 14786419.2016 .1219860$

80. Jafari NK, Sani AM. Chemical composition and antibacterial activity of essential oil from Melissa officinalis leaves. J Agric Biol Sci. 2016;11(9):367-372.

81. Pulaj B, Mustafa B, Nelson K, Quave CL, Hajdari A. Chemical composition and in vitro antibacterial activity of Pistacia terebinthus essential oils derived from wild populations in Kosovo. BMC Complement Altern Med. 2016;16:147. doi: 10.1186/s12906-016-1135-8

82. Teneva D, Denkova Z, Goranov B, et al. Chemical composition and antimicrobial activity of essential oils from black pepper, cumin, coriander and cardamom against some pathogenic microorganisms. Acta Universitatis Cibiniensis Series. E: Food Technol. 2016;20(2): 39-52. doi: 10.1515/aucft-2016-0014

83. Aliyah, Himawan A, Rante H, Mufidah Ningish DR. GCMS analysis and antimicrobial activity determination of Citrus medica L. var proper leaf essential oil from South Sulawesi against skin pathogen microorganism. IOP Conf Ser Mater Sci Eng. 2017;259:012001. doi: 10.1088/1757-899X/259/1/012001

84. Bozkurt T, Gulnaz O, Kacar YA. Chemical composition of the essential oils from some citrus species and evaluation of the antimicrobial activity. IOSR J Environ Sci Toxicol Food Technol. 2017;11(10):29-33. doi: 10.9790/2402-1110032933

85. Moosavy $\mathrm{MH}$, Hassanzadeh $\mathrm{P}$, Mohammadzadeh $\mathrm{E}$, Mahmoudi R, Khatibi SA, Mardani K. Antioxidant and antimicrobial activities of essential oil of Lemon (Citrus limon) peel in vitro and in a food model. J Food Qual Hazards Control. 2017;4:42-48.

86. Al-Aamri MS, Al-Abousi NM, Al-Jabri SS, Alam T, Khan SA. Chemical composition and in-vitro antioxidant and antimicrobial activity of the essential oil of Citrus aurantifolia L. leaves grown in Eastern Oman. J Taibah Univ Med Sci. 2018;13(2):108-112. doi: 10.1016/j. jtumed.2017.12.002

87. Shutava HG, Shutava TG, Kavalenka NA, Supichenka HN. Antiradical and Antibacterial activity of essential oils from the Lamiaceae family plants in connection with their composition and optical activity of components. Int J Second Metab. 2018;5(2):109-122. doi: 10.21448/ ijsm. 408165

88. Dagnas S, Membre JM. Predicting and preventing mold spoilage of food products. J Food Prot. 2013;76(3):538551. doi: 10.4315/0362-028X.JFP-12-349

89. Kurtzman CP, Fell JW, Boekhout T. The Yeasts, a taxonomic study, $5^{\text {th }}$ Ed.Elsevier. 2011.

90. Brennan TCR, Kromer JO, Nielsen LK. Physiological and transcriptional response to $d$-limonene in Saccharomyces cerevisiae shows changes to the cell wall, not the plasma membrane. Appl Environ
Microbiol. 2013;79(12):3590-3600. doi: 10.1128/ AEM.00463-13

91. Liu J, Zhu Y, Du G, Zhou J, Chen J. Response of Saccharomyces cerevisiae to D-limonene-induced oxidative stress. Appl Microbiol Biotechnol. 2013;97(14):6467-6475. doi: 10.1007/s00253-0134931-9

92. Munoz JE, Rossi DCP, Jabes DL, et al. In vitro and In vivo inhibitory activity of limonene against different isolates of Candida sp. J Fungi. 2020;6(3):183. doi: 10.3390/ jof6030183

93. Marei GIKh, Rasoul MAA, Abdelgaleil SAM. Comparative antifungal activities and biochemical effects of monoterpenes on plant pathogenic fungi. Pestic Biochem Phys. 2012;103:56-61. doi: 10. 1016/j. pestbp.2012.03.004

94. Dambolena JS, Lopez AG, Canepa MC, Theumer MG, Zygadlo JA, Rubinstein HR. Inhibitory effect of cyclic terpenes (limonene, menthol, menthone and thymol) on Fusarium verticillioides MRC 826 growth and fumonisin B1 biosynthesis. Toxicon. 2008;51(1):37-44. doi: 10.1016/j.toxicon.2007.07.005

95. Chee $\mathrm{HY}$, Kim H, Lee $\mathrm{MH}$. In vitro antifungal activity of limonene against Trchophyton rubrum. Mycobiology. 2009;37(3):243-246. doi: 10.4489/ MYCO.2009.37.3.243

96. Startseva VA, Nikitina LE, Sirazieva EV, et al. Synthesis and biological activity of monoterpenoids belonging to menthane series. Chem Sustain Dev. 2009;17:533-539.

97. Singh P, Shukla R, Prakash B, et al. Chemical profile, antifungal, antiaflatoxigenic and antioxidant activity of Citrus maxima Burm. and Citrus Sinensis (L.) osbeck essential oils and their cyclic monoterpene, DL- limonene. Food Chem Toxicol. 2010;48(6):17341740. doi: 10.1016/j.fct.2010.04.001

98. Omran SM, Moodi MA, Amiri SMBN, et al. The effects of limonene and Orange peel extracts on some spoilage Fungi. Int J Mol Clin Microbiol. 2011;1:82-86.

99. Rammanee K, Hongpattarakere T. Effects of tropical citrus essential oils on growth, aflatoxin production, and ultra structure alterations of Aspergillus flavus and Aspergillus parasiticus. Food Bioproc Tech. 2011;4:1050-1059. doi: 10.1007/s11947-010-0507-1

100. Tserennadmid R, Tako M, Galgoczy L, et al. Anti yeast activities of some essential oils in growth medium, fruit juices and milk. Int J Food Microbiol. 2011;144(3):480486. doi: 10.1016/j.ijfoodmicro.2010.11.004

101. Sokovic M, Glamoclija J, Ciric A, et al. Antifungal activity of the essential oils and components in vitro and in vivo on experimentally induced Dermatomycosis Rats. Dig J Nanomater Bio Structures. 2012;7(3):959-966.

102. Unal MU, Ucan F, Sener A, Dicner S. Research on antifungal and inhibitory effects of DL-limonene on some yeasts. Turk J Agric For. 2012;36(5):576-582. doi: 10.3906/tar-1104-41

103. Kostik V, Gjorgeska B, Petkovska S. Mentha L. essential oils composition and in vitro antifungal activity. IOSR J Pharm. 2015;5(7):1-7.

104. Antosik AK, Wilpiszewska K, Wroblewska A, Szczupak AM, Malko MW. Fragrant starch based films with limonene. Curr Chem Lett. 2017;6:41-48. doi: 10.5267/j.ccl.2017.2.002 
105. Novakovic M, Vuckovic I, Janackovic P, et al. Chemical composition, antibacterial and antifungal activity of the essential oils of Cotinus coggygria from Serbia. J Serbian Chem Soc. 2007;72(11):1045-1051. doi: 10.2298/JSC0711045N

106. Chutia M, Bhuyan PD, Pathak MG, Sarma TC, Boruah P. Antifungal activity and chemical composition of Citrus reticulata Blanco essential oil against phyto pathogens from North East India. LWT-Food Sci Technol. 2009;42(3):777-780. doi: 10.1016/j. Iwt.2008.09.015

107. Hamdan D, El-Readi MZ, Nibret E, et al. Chemical composition of the essential oils of two Citrus species and their biological activities. Pharmazie. 2010;65(2):141-147. doi: 10.1691/ph.2010.9731

108. Kirbaslar FG, Tavman A, Dulger B, Turker G. Antimicrobial activity of Turkish citrus peel oil. Pak J Bot. 2009;41(6):3207-3212.

109. Hyun LJ, Lee JS. Chemical composition and antifungal activity of plant essential oils against Malassezia furfur. Korean J Microbiol Biotechnol. 2010;38(3):315-321.

110. Oliva MM, Beltramino E, Gallucci N, Casero C, Zygadlo J, Demo M. Antimicrobial activity of essential oils of Aloysia triphylla (L'Her.) Britton from different regions of Argentina. Bol Latinoam Caribe Plantas Med Aromat. 2010;9(1):29-37.

111. Tanackov SDK, Dimic GR. Antifungal activity of essential oils in the control of food-borne fungi growth and mycotoxin biosynthesis in food. Microbial pathogens and strategies for combating them: science, technology and education. 2013;838-849.

112. Trabelsi D, Ammar AH, Bouabdallah F, Zagrouba F. Antioxidant and antimicrobial activities of essential oils and methanolic extracts of Tunisian Citrus aurantium L. J Environ Sci Toxicol Food Technol. 2014;8(5):18-27. doi: 10.9790/2402-08521827

113. Fattah A, Yehia HA, Fouzy ASM, Ramadan MM, Nooh A. Antifungal efficacy and chemical composition of essential oil from the Egyptian sweet orange peel (Citrus sinensis, L). Int J Adv Res. 2015;3(10):12571269.

114. Hafez EA. Antimicrobial activity of Bergamot oil against Trichophyton verrucosum isolated from local cows. J
Biochem Microbiol Biotechnol. 2015;3(1):7-9.

115. Azhdarzadeh F, Hojjati M. Chemical composition and antimicrobial activity of leaf, ripe and unripe peel of Bitter orange (Citrus aurantium) essential oils. Nutr Food Sci Res. 2016;3(1):43-50. doi: 10.18869/acadpub. nfsr.3.1.43

116. Mobin M, De Lima SG, Almeida LTG, et al. MD/GC-MS analysis of essential oils from Protium heptaphyllum (Aubl.) and their antifungal activity against Candida specie. Braz J Med Plants. 2016;18(2):531-538. doi: 10.1590/1983-084X/15_110

117. Al-Gendy AA, El-Sayed MA, Hamdan DI, El-Shazly AM. Volatile constituents, antimicrobial and cytotoxic activities of Citrus reticulata Blanco Cultivar Murcott. Int J Pharmacogn Phytochem Res. 2017;9(3):376-386. doi: $10.25258 /$ phyto.v9i2.8089

118. Hsouna AB, Hamila NB, Smaoui S, Hamdi N. Citrus lemon essential oil: chemical composition, antioxidant and antimicrobial activities with its preservative effect against Listeria monocytogenes inoculated in minced beef meat. Lipids Health Dis. 2017;16:146. doi: 10.1186/s12944-017-0487-5

119. Alasil SM, Omar R, Ismail S, Yusof MY. Anti-biofilm activity, compound characterization, and acute toxicity of extract from a novel bacterial species of Paenibacillus. Int J Microbiol. 2014;2014:649420. doi: $10.1155 / 2014 / 649420$

120. Subramenium GA, Vijayakumar K, Pandian SK. Limonene inhibits streptococcal biofilm formation by targeting surface-associated virulence factors. $J$ Med Microbiol. 2015;64(8):879-890. doi: 10.1099/ jmm.0.000105

121. Espina L, Pagan R, Lopez D, Gonzalo DG. Individual constituents from essential oils inhibit biofilm mass production by multi-drug resistant Staphylococcus aureus. Molecules. 2015;20(6):11357-11372. doi: 10.3390/molecules200611357

122. Nosrati M, Behbahani M, Mohabatkar H, Shakeran Z. Antibacterial and anti biofilm activities of Prangos acaulis Bornm. extract against Streptococcus mutans: an in silico and in vitro study. J Herb med Pharmacol. 2018;7(3):176-184. doi: 10.15171/jhp.2018.29 